with experimental data on the action of positive ions in a diatomic gas (hydrogen) in a uniform field ${ }^{18}$.

It is hoped to publish elsewhere fuller results and discussion of the present experiments. We wish to acknowledge the assistance of Mr. J. Dutton in making observations.

1 Townsend and MacCallum, Phil, Mag., 6, 857 (1928); 17, 678 (1934), Penning and Addinck, Physica, 1, 1007 (1934).

'Townsend, Phil. Mag., 45, 444 (1923).

- Llewellyn Jones and Henderson, Phil. Mag., 28, 185 (1939); 28 192 (1939); 28, 328 (1939).

"Loeb and Meek, "The Mechanism of the Spark Discharge" (StanPress, 1940).

- Teszner, Bull. Soc. franc. Electriciens, 6, 1 (1946).

'Masch, Arch. Elektrotech., 26, 589 (1932).

- Hochberg and Sandberg, J. Tech. Phy8. U.S.S.R., 12, 65 (1942),

- Sanders, Phys. Rev., 41, 667 (1932) ; 44, 1020 (1933).

10 Parvola, Arch. Elektrotech., 22, 443 (1929).

"Varney, White, Loeb and Posin, Phys. Rev., 48, 818 (1935).

12 Raether, $Z$. Phys., 112, 464 (1939).

13 Zeleny, J. App. Phys., 13, 103 and 444 (1942).

24 Medicus, $Z$. angewo. Phys., 1, 106 (1948); 1, 316 (1949).

18 Fisher and Bederson, Phys. Rev., 75, 1615 (1949).

16 Ganger, Arch. Elektrotech., 39, 508 (1949).

${ }^{17}$ Ilewellyn Jones, British Science News (British Council), 2, 263 (1949).

28 Townsend and Llewellyn Jones, Nature, 130, 398 (1932); Phil. Mag., 15, 282 (1933).

\section{COAL TAR RESEARCH ASSOCIATION}

\section{NEW RESEARCH STATION AT GOMERSAL}

$\mathrm{T}$

HE new Research Station of the Coal Tar Research Association was formally opened by the Right Hon. Sir John Anderson on May 12 in the presence of some seventy guests representing the tar producing and distilling industries, the Department of Scientific and Industrial Research, interested academic institutes, other research associations and the technical and newspaper Press.

The opening ceremony took the form of the symbolic act of lighting a bunsen burner; before this, however, in commenting on the introductory remarks of the Association's president, Dr. E. V. Evans, that it might seem strange that an industry of the national importance of the coal tar industry should only in recent times have founded a central research association, Sir John offered a historical explanation. The coal tar industry, he pointed out, was a traditional industry in which skill and know. ledge were handed down from generation to generation and which served the country well until, with the intensification of foreign competition and the growth of new industries based on the direct application of new scientific discoveries, the economic circumstances changed early in the present century. Such traditional industries are having more and more to equip themselves scientifically and to introduce scientific methods into their operations. Sir John felt that the coal tar industry-which had served the country well in the past-would serve the country even better in the future when it had the organising and co-ordinating service of the Research Association behind it.

After the ceremony the guests inspected the Research Station. This is a converted mill situated at Gomersal, about nine miles from Leeds. The buildings consist of a one-story stone structure of 24,500 sq. ft. floor area and an adjoining twostory brick building of 7,000 sq. ft. floor area. The upper story of the latter has been divided into eight offices, the library, a conference room, dining hall and kitchen, and the lower story houses the stores and glassblower's workshop. To these will be added a reception room and a first-aid room. 14,500 sq. ft. of the main single-story building has been divided by glazed partitions into six main laboratories, two smaller laboratories, a fully equipped machine-tool shop, a reinforced autoclave room, a balance room and offices for the research section leaders.

Since in the early stages of the Association's life the greater part of the work is likely to be on a laboratory scale, the main laboratories, with the exception of the catalytic laboratory and the semitechnical laboratory, have been furnished in more or less conventional fashion with teak-topped benches, oak-block flooring and fluorescent lighting. Every laboratory has several fume-cupboards, each operated by a separate fan. In the catalytic and semi-technical laboratories the services terminate at selected points on the walls, around which the various plant can be built ; in these laboratories flame-proof lighting and switch gear have been installed. The services installed in the laboratories are restricted to gas, water, electricity and 60-lb./sq. in. steam. Vacuum, compressed air and low-voltage D.C. current can be supplied at any desired point by portable pumps, compressors or generators.

Although the Association was not incorporated until February 1949, conversion of the premises commenced in that month and was completed by the end of the year. The cost of conversion and of the initial equipment was met from the income of the Association's first year. At present the establish. ment numbers sixty, including eighteen graduate chemists and twenty-one assistant chemists; the director is Dr. D. MeNeil.

During their tour of the laboratories, guests saw many exhibits illustrating the processes carried out by the tar-distilling industry and the problems which the industry faces. In the development laboratory models of the different types of tar stills at present used were shown, and the diverse results obtained using such plant on different tars were illustrated. This provided the background for the Association's research programme of comparative tar assays designed to give more quantitative information about the chemical composition of coal tar and the effects of carbonization and distillation conditions thereon. A number of exhibits illustrated the two major problems encountered in industrial primary distillation, namely, corrosion and carbon deposition, and the work at present being carried out at Gomersal on these subjects was outlined.

In the organic laboratory an extensive collection of specimens of the industrial components identified in, or isolated from, coal tar was displayed, together with specimens of plastics, dyestuffs, drugs, etc., derived from them; also shown were the derivatives so far prepared as part of the Association's research projects on the utilization of fluorene, phenanthrene and pitch oils. It was, however, strongly emphasized that the commercially pure products of coal tar refining used as intermediates in the chemical and allied industries make up only 10-15 per cent of the total products, and that it is a paramount necessity for the industry to foster the present outlets and to devise new outlets for the bulk products-pitch and creosote.

The preparation of catalysts, apparatus for the study of fluidized and solid-bed catalytic cracking of creosote, for the vapour- and liquid-phase catalytic oxidation of creosote fractions and for the carbon. 
ization of pitch were demonstrated in the catalytic laboratory, while in the physical laboratory the exhibits illustrated work on the separation of the aromatic and non-aromatic fractions of creosote by selective adsorption on silica gel and by solvent extraction. Other exhibits in this laboratory concerned the study of the colloid structure of tar and the separation and utilization of tar resins. A comprehensive range of instruments for determining the physical properties of tars and pitch was shown partly in the physical laboratory and partly in the analytical laboratory, which also contained examples of semi-micro methods for elementary and gas analyses and for molecular-weight determinations. Perhaps the most interesting and impressive equip. ment displayed was the battery of automatic high. efficiency fractionation columns. Two of these units have efficiencies in excess of eighty theoretical plates, while the remainder are rated at fifty plates. All controls are automatic in operation, enabling the columns to operate with the minimum of supervision.

In his concluding remarks at a reception held after the inspection of the Station, Mr. R. B. Robinson, the chairman of the Association, made a strong appeal to members of the Association to interest themselves in the work and to make use of the facilities of their research organisation. Membership involves greater obligations than merely paying a subscription. It entails an active partnership and a lively interest in the work of the Association; without this the Association cannot hope to make its full contribution to the welfare of the industry.

\section{MARINE ENGINEERING TURBINE RESEARCH}

\section{INSPECTION OF THE PAMETRADA RESEARCH STATION AT WALLSEND}

$\mathrm{O}^{\mathrm{s}}$ $\mathrm{N}$ May 26, to mark the occasion of the completion of its first five years of work on marine engineering turbine research, the Pametrada Research Station at Wallsend, on the River Tyne, was open for inspection by invited guests and representatives of the Press. The word 'Pametrada' is an abbreviation for the Parsons and Marine Engineering Turbine Research and Development Association, which owns and operates the research station. The Association was formed in May 1944 by a collective effort of British shipbuilding and marine-engineering firms to continue the research work on marine turbines initiated by the late Sir Charles Parsons before the beginning of this century. The Research Station is equally concerned with both steam turbines and gas turbines for marine propulsion, and during the visit examples of each were on view undergoing full-scale trials on the test bed. Never before have such largescale facilities been available in Great Britain for testing marine turbines and gearing at full load.

The steam turbine on view was a prototype of the Daring Class $1 A$ propelling machinery for the Admiralty and was coupled to a large hydraulic brake capable of absorbing 60,000 shaft horse-power at 150 r.p.m. The Daring boiler and a Frigate boiler were also to be seen in a specially designed boilerhouse which can itself be subjected to a pressure slightly above atmospheric in order to simulate working conditions in certain types of ship. The centre of interest was, however, the 3,500-h.p. marine gas turbine which was also in the turbine test-house and coupled to a dynamatic brake.

The visitors were shown around various buildings at the Research Station, the testing of sprayers for gas turbines, torque-meter calibrating equipment, gear-pitch comparators for very large gears, and a wide variety of testing equipment and apparatus in the Electronics Laboratory, Applied Physics Laboratory and Chemical and Metallurgical Laboratories.

This display of up-to-date equipment for engineering research was demonstrated by members of the staff, which now numbers nearly two hundred. It is a tribute to the director of research, Dr. T. W. F. Brown, that, not only has he assembled this staff and equipment and housed them in new buildings during the difficult post-war period, but at the same time has also pressed forward with turbine designs for more than sixty-five installations that have been built or are now under construction; and in the process, a large number of patents have been granted to the Association, and many technical reports have been issued to the member firms.

A most unusual feature of the Association is that the results of its work are disseminated not only in the form of reports of research investigations but also as preliminary designs of propelling machinery, which are sent out to the member firms in response to specific inquiries. The designs vary considerably according to type of service for which the vessel is required. The Association has also served its member firms by investigating occasional defects in machinery such as turbine blade vibrations, a hitherto intractable subject, to which it has already contributed new knowledge and new apparatus. A wave analyser and a wave correlator developed at the Research Station have proved singularly successful for vibration diagnosis in marine geared turbines and in studying the origin and suppression of noises in turbine machinery.

Some preliminary designs for marine gas turbines have been prepared for member firms, and a small experimental unit has been designed for Messrs. John Brown and Co., Ltd., of Clydebank, where it has already run for a thousand hours. Many other designs have been worked out for naval vessels, in addition to the detailed design of the Association's 3,500-h.p. marine gas turbine which was seen running on the test bed at Wallsend. The latter is of the open-cycle type with series flow from the highpressure turbine which drives the two axial-flow compressors to the low-pressure power turbine which drives the ship's propeller. The two turbines are mechanically independent. An exhaust heatexchanger is provided and also intercooling between the two compressors. The installation has been assembled on the test bed in a manner conforming to the restricted space available in a ship's hull, so that any problems of loading and differential expansion which may be met at sea are likely to be experienced on the test bed. The present machine has been designed for a turbine inlet temperature of $1,200^{\circ}$ F. $\left(650^{\circ}\right.$ C. $)$, which is limited by the creep strength of the best turbine-blade materials available for the period of service required in a marine installation. After extensive trials of this gas turbine unit at the Pametrada Research Station at Wallsend, it is to be installed in a merchant ship for trials at sea.

Elaborate and extensive instrumentation has been provided for analysing performances of marine turbine machinery on the test bed and seems justified 